\title{
Empowerment Community Leaders as to Strengthen the Implementation of Regional Autonomy
}

\author{
I Gusti Ayu Ketut Rachmi Handayani ${ }^{1}$, Lintje Anna Marpaung ${ }^{2}$, Guntur Hamzah ${ }^{3}$, Yuliandri ${ }^{4}$ \& Anis \\ Mashdurohatun $^{5}$ \\ ${ }^{1}$ Universitas Sebelas Maret, Indonesia \\ ${ }^{2}$ Universitas Bandar Lampung, Indonesia \\ ${ }^{3}$ Universitas Hasanuddin, Indonesia \\ ${ }^{4}$ Universitas Andalas, Indonesia \\ ${ }^{5}$ Universitas Islam Sultan Agung, Indonesia \\ Correspondence: I Gusti Ayu Ketut Rachmi Handayani, Universitas Sebelas Maret, Indonesia. E-mail: \\ ayu_igk@staff.uns.ac.id
}

Received: July 15, 2017

doi:10.5539/jpl.v10n5p29
Accepted: August 30, $2017 \quad$ Online Published: November 17, 2017

URL: https://doi.org/10.5539/jpl.v10n5p29

\begin{abstract}
The local government together with community leaders consisting of traditional leaders, religious leaders, and NGOs need to work together in building the region so that it can thrive again and be able to strengthen the character of Indonesian society, in a society that increasingly modern and multicultural. With the cooperation, areas that initially the potential for conflict, it can be prevented by approaches are persuasive by the community leaders, to be more tolerant and try to take advantage or learn from the conflict. The principles of cooperation between local government and community leaders in strengthening regional autonomy in general that good governance principles that can be used as a guide in conducting cooperation between community leaders with local.
\end{abstract}

Keyword:empowerment, government, leaders, society, autonomy

\section{Introduction}

Some time later since the passing wave of reform, regional autonomy is one of the central topics are widely discussed. Regional autonomy became discourse and study material from various groups, including government, people's representative institutions, academics, economists and even the general public. All parties talk and comment about "autonomy" according to the understanding and perception of each. Differences in the understanding and perception of various groups of regional autonomy greatly due to differences in viewpoints and approaches used. Actually the "autonomy" is not a new thing because since the founding of the Republic of Indonesia, the concept of regional autonomy already in use in governance in the region. Even on the Dutch colonial rule, the principles of autonomy already partially implemented in governance. ${ }^{1}$

NKRI, as stated in Article 1, Paragraph 1 of the 1945 Constitution in conjunction with Article 37, Paragraph 5 of the 1945 Constitution and as a pluralistic country, consisting of various tribes, religion, race, and class of each region. The state becomes the existence of indigenous traditions of a region, as stipulated in Article 18B paragraph 2 in conjunction with Article 32 paragraph 1 in conjunction with Article 28i paragraph 3 of the 1945 Constitution With the enactment of the Law on Regional Autonomy, then one important element in the implementation of regional autonomy is needed implementation regional administration on the initiative, creativity and active role in community development and develop the region.

Autonomous region apparently has been perceived and addressed varied by some local governments in Indonesia. For example they perceive autonomy as a momentum to meet the desires of its own country regardless of the broader context, namely the interests of the country as a whole and the interests of other neighboring areas. As a result, there were some negative symptoms were troubling among other things the development of primordial

\footnotetext{
${ }^{1}$ Josef Riwu Kaho, 1991, Prospek Otonomi Daerah Di Negara RI, Jakarta: Rajawali Pers, p.8
} 
sentiment, conflicts between regions, the development process of corruption, conflicts between residents, the exploitation of natural resources in excess, and the emergence of an attitude of "ego areas" excessive. ${ }^{2}$ National development objectives Indonesia, namely that mentioned in the Preamble of the Constitution of 1945 Paragraph 4 which reads "realize just and prosperous society, material and spiritual, based on Pancasila and the Constitution of 1945, to protect all the people of Indonesia and the country of Indonesia and to promote the general welfare, educating the nation and participate in implementing world order based on freedom, lasting peace and social justice". Referring to the significance of development which is also the national commitment Indonesian Nation, as stated above, meaning to realize the need to increase the role of the government official.

There is no harm in all regions in Indonesia through community leaders to revive the local culture and distinctive forms of local wisdom, because it can serve as the means of adhesive society, with various differences. It will succeed if supported by religious leaders, traditional institutions, NGOs, other public institutions and government. The role of the mass media is very important as a means of social glue, so expect the mass media always tries to package messages polite and persuasive.

To minimize social conflicts, repressive approach should be the last option in resolving the conflict, and multicultural approach is an important alternative that can be used to minimize conflict in the country. While the local government together with community leaders need to work together to build the area so they can thrive again and be able to strengthen the character of Indonesian society, in a society that increasingly modern, multicultural and very quickly changed.

Based on the above, the issues to be discussed are:

1) Why the need for cooperation between public figures with the local government in empowering community leaders in strengthening local autonomy?

2) How the principles of cooperation between local government and community leaders in strengthening local autonomy?

The method used in this research is normative juridical and hermeneutics. Hermeneutics is derived from the Greek word hermeneuine and hermeneia respectively mean "interpreting" and "interpretation". ${ }^{3}$ This research was conducted through literature study and data analysis with qualitative analysis. Data collection and processing procedures, after the data were analyzed by means of structured juridical analysis performed by way of sort or give notions of data that has been compiled systematically. The theory used is volkgeist theory and the theory of participation. Based on the theory volkgeist, all law initially formed in a manner as they say, customary law, to discuss the usual but not too fast, formed, that the law was started initially developed by the customs and beliefs are common. While the theory of participation is involvement of a group or society as a whole.

\section{Discussion}

\subsection{Cooperation with the Community Leaders in Strengthening Local Government Autonomy}

In connection with the implementation of the reform policy of regional governance in Indonesia, which should be understood by all parties is the meaning and significance of the reform itself correctly, that the reform as a step change towards improvements without damaging or while maintaining the initiated by those who lead a system. It is important to realize that without reform the system could falter, or in other words, the reform should be initiated from the system itself so that the method of reform will be gradual, gradual and continuous.

Therefore, the direction of policy reform and reorientation in the administration of local government in Indonesia should refer to the various problems that had always been used as a matter of debate in conducting the study on the relationship of the Central Government and the Regions, among others, are clogging the participation and involvement of the public due to their tendencies and a strong presumption that it is the government which has a great responsibility in implementing development activities and public policies. As a result, many development activities and public services that should be handed over to forces outside of government such as NGOs or private parties, is fully carried out by the Government, including Local Government.

To realize autonomy for the region to have flexibility in governance in the area, then according to Agus Syamsuddin ${ }^{4}$ associated with some of the following:

\footnotetext{
${ }^{2}$ Heru Nugroho, 2000, Eksistensi Lembaga Lokal dan Permasalahannya di tengah Era Reformasi (Paper), p. 8.

${ }^{3}$ Mudjia Raharjo, 2008, Dasar-Dasar Hermeneutika: Antara Intensionalisme dan Gadamerian.Yogyakarta: Ar-Ruzz Media, p. 27-28.

${ }^{4}$ Agus Syamsuddin, 2000, Mengenal Otonomi Daerah Berdasarkan Undang-Undang Nomor 22 Tahun 1999 tentang Pemerintahan Daerah, (Paper), Seminar of Kadin-PWI Kabupaten Bondowoso, p. 5.
} 
1) First, Self Regulating Power, namely the ability to organize and implement regional autonomy for the welfare of the community.

2) Second, Self Modifying Power, namely the ability to make adjustments of the rules established in the State to local conditions.

3) Third, Local Political Support, which govern areas that have broad legitimacy of the public, both in the position of Regional Head as the executive element although Parliament as the legislative bodies. Support local political will both ensure the effectiveness of governance and development.

Each region has its administrative borders were defined formally through legislation, but in reality the problems and interests often arise as a result of the functional relationship in socio-economic field that passes through the boundaries of the administrative regions. In this context, the main reason it needs cooperation between community leaders and local government is that the various problems across administrative areas can be solved together as community leaders are people who certainly understands the surrounding area that may be related to the boundaries of his territory and so much potential they possess can be utilized for the common good. The consequence is the need to reform microorganizationnal abilities of Government at the local level which is a form of public management reforms to be aware of the current government, and not merely fix macroorganizational capacities at the central level. ${ }^{5}$ In other words, improvement of the institutional capacity under the central government is indispensable.

Another reason to do cooperation among community leaders and local governments is as follows:

1) The parties can work together to form a larger force. With cooperation among community leaders and local government, the strength of each regional cooperation can be synergized to confront environmental threats or problems that complicated nature than if dealt with individually. They can work together to overcome environmental obstacles or reach higher levels of productivity.

2) The parties are cooperating to progress higher. With the cooperation, each region will transfer intelligence, skills, and information, for example, one area of learning or skill excess of other areas. Each region will strive to advance or develop itself from the results of learning together.

3) The parties can work together to minimize or prevent conflicts. With the cooperation, areas that originally the potential for conflict, can be prevented by a persuasive approaches of community leaders, to be more tolerant and try to take advantage or learn from the conflict. The reason is of course essential for public figures is the elder person and respected in the area and of course the advice it provides to the community is still very influential and heard in terms of reducing conflict will occur.

4) Each party is felt justice. Each region will find itself not harmed because there is no transparency in the relationship of cooperation. Each region involved cooperation have equal access to information created or used.

5) Each of the parties will cooperate sustaining treatment areas of cooperation. With the cooperation of each region are committed to not betray his partner but maintain a mutually beneficial relationship in a sustainable manner.

In the future, because of the cooperation between the community and the local government should be seen as an essential requirement of the inevitable then there must be a systematic effort and sustained by the government to introduce and encourage cooperation between the community and the local government to local governments are accustomed do and can take the benefits.

Cooperation made must also pay attention to the ability of local community leaders, lest such cooperation becomes a burden to the traditional leaders. This can cause serious problems because theoretically a transfer of authority to a party that does not take into consideration the ability of the parties concerned, the delivery will be a source of problems later in life. ${ }^{6}$

In reality, the level of ability of community leaders to provide support for cooperation in agriculture, industry and trade, development of infrastructure and facilities area, setting agreement about the spatial arrangement, and the settlement of disputes between district/ city, is also unknown. Identification and planning of the areas in which cooperation is rarely done unless there is a serious problem that demands immediate attention. This should be recognized for that cooperation among community leaders and the government has not been perceived as a necessity that is not taken into account in the planning process. Whereas various problems or an internal decision

\footnotetext{
${ }^{5}$ Pollit, C. \& G.Bouckaert, 2000, Public Management Reform: A Comparative Analysis. New York: Oxford University Press, p. 10.

${ }^{6}$ Keban, Y.T, 2004, EnamDimensi Strategis Administrasi Publik: Konsep, Teori dan Isu. Yogyakarta: Gava Media, p. 115.
} 
of a City/County often associated with community leaders in the area.

Historically, the mechanism of cooperation among local governments has become an important issue in developed countries ${ }^{7}$ starting from a very limited field such as the police and fire departments where between one city to another city has made cooperation agreements help each facing a crisis such as fire and other disasters. In a further development, this cooperation mechanism is not only applied to the situation of "emergency" but also on the cooperation arrangements for the purchase of certain types of services from private companies or from other governments. Special "cooperative agreements" were made between the Local Government originally aimed more at:

(1) a single activity,

(2) with respect to services rather than facilities,

(3) temporary,

(4) as a "stand-by provision" newly implemented when certain conditions occur,

(5) allowed/permitted by the legislature.

Indonesian State should also be able to apply the cooperation that started from cooperation between community leaders and local government to improve, develop and promote the region in accordance with the principles of local autonomy and the norm of the applicable legislation. Cooperation is done either in writing or not writing beforehand with the perception that the cooperation between the community leaders and local government is in the interest of the community and develop the region.

Cooperation arrangements (Forms of Cooperation Arrangements) consists of some form of. ${ }^{8}$ Namely:

a) Consortia: the setting up of cooperation in the sharing of resources, because it is more expensive when borne singly;

b) Construction Cooperative: namely cooperation arrangements in the building, such as a recreation center, library, parking locations, theater, etc.

c) Joint Services: the setting up of cooperation in providing public services,

d) Other settings: other cooperative arrangements can be made for keeping down costs, etc.

Nevertheless, experience shows that the above forms and methods of cooperation often encounter problems in implementation. ${ }^{9}$ As it relates to the involvement of each region has different jurisdictions, then there is difficulty in setting an agreed schedule of resource use and charging of cooperation, which in turn often led to friction or conflict. This often happens because there are community leaders feel their loadings are (overcharge) against him, while others feel underserved he should have received. Often, there is difficulty in meeting the expectations of the parties to cooperate.

It must be recognized that during the cooperation between community leaders and the local government has not appeared as a necessity. In fact, various problems or an internal decision of a district or a city or a province is also often associated with indigenous issues. Experience shows that many problems in a district or city or province either just come to the surface due to the policy coming from the area. Under these conditions, the planning functions integrative and horizontal coordination is the key.

The emergence of the model "integrated area planning" is expected to reduce the various conflict areas, namely by effecting the development of specific sectors and institutions related to the sector in an area (with the exclusion of the boundaries of administrative area). This model emerged as a reaction to the shortcomings of sectoral planning in particular coordination between sectors, and also to meeting the needs of the geographical area special (which may not correspond to the boundaries of existing administrative) as watersheds (DAS) and rural development then known as the "integrated rural development".

\subsection{Principles of Cooperation between the Regional Government and Community Leaders in Strengthening Regional Autonomy}

In order to successfully implement such cooperation takes the general principles as contained in the principle of

\footnotetext{
${ }^{7}$ Henry, N, 1995, Public Administration and Public Affairs. Sixth Edition. Englewood Cliffs, N.J.: Prentice, p. 76.

${ }^{8}$ Rosen, E.D, 1993, Improving Public Sector Productivity: Concept and Practice. London: Sage Publications, International Educational and Professional Publisher, p. 218-222.

${ }^{9}$ Ibid., p. 223.
} 
"good governance". ${ }^{10}$ Some among the principles of good governance there can be used as guidelines in cooperation between community leaders with local governments, namely:

\section{1) Transparency}

Local Government that has Agreed to conduct cooperation should be transparent in providing the the data and information needed in order to Strengthen local autonomy, with no cover-up.

\section{2) Accountability}

Local Government has Agreed to cooperate should be willing to account for and disclose all program activities activities activities In These areas to community leaders as representatives of the people in strengthening local autonomy.

\section{3) Participatory}

Within the scope of cooperation between local government and community leaders, the principle of participation should be used in the form of consultation, dialogue and negotiation in Determining the goals to be Achieved, how to Achieve and measure its performance, Including how to divide the compensation and risk.

4) Efficiency.

In implementing the cooperation between local government and traditional leaders should Consider the efficiency of the which is how to reduce the cost to Obtain A Certain result, or how to use the same cost but can Achieve higher yields.

5) Effectiveness.

In implementing the cooperation between local government and community leaders should Consider the value of the effectiveness of the which is always measured success by Comparing the targets or goals set in cooperation with tangible results Obtained.

6) Consensus.

In carrying out such cooperation should be sought common ground so that each of the parties Involved in the agreement may agree on a decision. Or in other words, unilateral decisions are unacceptable in such cooperation.

7) Mutual benefit and advance.

In the cooperation between local Governments and community leaders need to be adhered to the principle of mutual benefit and mutual respect. This principle should hold true in all decisions and cooperation mechanism.

In addition to the seven general principles above, some specific principles that can be used as a reference in the cooperation between local government and community leaders, ${ }^{11}$ namely:

a. Such cooperation must be built for the public interest and the wider interest.

b. Entanglement is woven in such cooperation should be based on mutual need.

c. The existence of such cooperation must reinforce each other involved parties.

d. There must be engagement of each party to the treaty agreed.

e. Must be orderly in the implementation of cooperation as has been decided.

f. Cooperation should not be political and nuanced corruption.

g. Cooperation must be built on mutual trust, mutual respect, mutual understanding and benefits that can be taken by both parties.

If the principles of the cooperation of a conflict or friction between local government and community leaders, the approach used is the approach interactionist, and not the traditional approach. ${ }^{12}$ The traditional approach assumes that conflict is always bad, and negative effects. Therefore, according to this approach, the conflict should be avoided because it can lead to evil, destructive and irrational. But in the interactionist approach, conflict is seen as a stimulus for change. Conflicts should be root, and the root can be done a variety of repair and renewal. Conflicts should be seen as an indicator to initiate change. To address the various issues that arise in the conflict, required adequate capability to act as a negotiator, facilitator, mediator and communicator, ${ }^{13}$ On

\footnotetext{
${ }^{10}$ Edralin, J.S, 1997, The new local governance and capacity building: A strategic approach. InRegional Development Studies, Vol. 3.

${ }^{11}$ Ibid.,

${ }^{12}$ Robbins, S.P, 1990, Organization Theory: Structure, Desain and Applications (Third Edition). Englewood Cliffs, NJ.: Prentice Hall, Inc.

${ }^{13}$ Mayer, B., 2000 The Dynamics of Conflict Resolution: A practitioner's guide. San Fransisco: Jossey-Bass, p. 19.
} 
the part of local government and community leaders.

The last thing to consider to sustain the effectiveness and sustainability of cooperation between local government and community leaders are forming a strong partnership basis. This is in accordance with the paradigm of building relationships between organizations in the form of networks and strategic alliances. ${ }^{14}$ It is time, as the paradigm, any organization or government institutions develop strong external relationships with other organizations in order to provide the best to the community.

\section{Conclusion}

In strengthening local autonomy need for cooperation between the leaders of communities and local governments to empower community leaders for community leaders are people who definitely understand the conditions in the region. Another reason does the cooperation between community leaders and local governments is to establish a greater power, can achieve a higher, can reduce or prevent conflicts.

The principles of cooperation between local government and community leaders in strengthening local autonomy in general that good governance principles that will guide cooperation between the leaders of communities and local government among other things: transparency, accountability, participation, efficiency, effectiveness, consensus, mutual benefit and advancing.

\section{References}

Edralin, J. S. (1997). The New local governance and capacity building: A strategic approach. Regional Development Studies, 3.

Henry, N. (1995). Public Administration and Public Affairs (6th ed.). Englewood Cliffs, N.J.: Prentice.

Kaho, J. R. (1991). Prospek Otonomi Daerah Di Negara RI. Jakarta: Rajawali Pers.

Keban, Y. T. (2004). EnamDimensi Strategis Administrasi Publik: Konsep, Teori dan Isu. Yogyakarta: Gava Media.

Limerick, D., \& Cunnington, B. (1993). Managing the New Organization: A blueprint for networks and strategic alliances. West Castwood, Australia: Business \& Professional Publishing.

Mayer, B. (2000). The Dynamics of Conflict Resolution: A practitioner's guide. San Fransisco: Jossey-Bass.

Nugroho, H. (2000). Eksistensi Lembaga Lokal dan Permasalahannya di tengah Era Reformasi (Paper).

Pollit, C., \& Bouckaert, G. (2000). Public Management Reform: A Comparative Analysis. New York: Oxford University Press.

Raharjo, M. (2008). Dasar-Dasar Hermeneutika: Antara Intensionalisme dan Gadamerian. Yogyakarta: Ar-Ruzz Media.

Robbins, S. P. (1990). Organization Theory: Structure, Desain and Applications (3rd ed.). Englewood Cliffs, NJ.: Prentice Hall, Inc.

Rosen, E. D. (1993). Improving Public Sector Productivity: Concept and Practice. London: Sage Publications, International Educational and Professional Publisher. https://doi.org/10.4135/9781483326276

Syamsuddin, A. (2000). Mengenal Otonomi Daerah Berdasarkan Undang-Undang Nomor 22 Tahun 1999 tentang Pemerintahan Daerah. Seminar of Kadin-PWI Kabupaten Bondowoso.

\section{Copyrights}

Copyright for this article is retained by the author(s), with first publication rights granted to the journal.

This is an open-access article distributed under the terms and conditions of the Creative Commons Attribution license (http://creativecommons.org/licenses/by/4.0/).

\footnotetext{
${ }^{14}$ Limerick, D. \& B.Cunnington, 1993, Managing the New Organization: A blueprint for networks and strategic alliances. West Castwood, Australia: Business \& Professional Publishing.
} 